\title{
Moringa oleifera Lam.: A Biofunctional Edible Plant from India, Phytochemistry and Medicinal Properties
}

\author{
V. N. Pandey ${ }^{1}$, Vandana Chauhan ${ }^{1}$, V. S. Pandey ${ }^{1}$, P. P. Upadhyaya ${ }^{1} \&$ Olga R. Kopp ${ }^{2}$ \\ ${ }^{1}$ Experimental Botany and Nutraceutical Laboratory, Department of Botany, DDU Gorakhpur University, \\ Gorakhpur, India \\ ${ }^{2}$ Utah Valley University, 800 West University Parkway MS 299. Orem, UT, USA
}

Received: July 17, 2018

Accepted: August 2, 2018 Online Published: January 27, 2019

doi:10.5539/jps.v8n1p10

URL: https://doi.org/10.5539/jps.v8n1p10

\begin{abstract}
Moringa oleifera is a versatile horticulture tree with important medicinal, nutritional and industrial applications, widely distributed and used in India. The Moringa tree originated in India and was introduced to Africa from India and other countries as a health supplement. Almost all parts of the plant have shown nutritional value and are used in India for a variety of food preparations. In India, M. oleifera leaves are available in powder to treat mild malnourishment in children. About all parts like leaves, seeds and pods are used as vegetables. Phytochemicals such as flavonoids, tannins, triterpenoids, saponins, flavonoids, anthraquinones, alkaloids and others, are responsible for the medicinal value of this plant. This species is rich in protein, fatty acids, vitamins and minerals that form part of its quality as superfood. It has been reported to have strong antimicrobial, antioxidant, anti-inflammatory, hepatoprotective, diuretic, anthelminthic and antiurolithiatic properties, among others. People in India use this species to treat common illnesses because of its availability and easy preparation. This review provides information on the significant potential of Moringa and its nutritional, medicinal, pharmaceutical and industrial values.
\end{abstract}

Keywords: Moringa oleifera, medicinal value, phytochemicals, underutilized nutritional plant

\section{Introduction}

The genus Moringa belongs to the monogeneric family Moringaceae and comprises thirteen species distributed from semi-arid Africa to Asia. Of these, M. oleifera Lam. (Figure 1) is the most commonly known species distributed in the northwest India (Mabberley, 2017; Nadkarni, 1976; Ramachandran et al., 1980; Jahn 1988; Somali et al., 1984; Mughal et al., 1999,). The tree ranges in height from 5 to 10m (Morton, 1991). This tree grows rapidly, with recording growth of 6-7 $\mathrm{m}$ in areas with rainfall of less than $400 \mathrm{~mm}$ per year (Odee, 1998). Although it is wild in NW India, it can be cultivated in different areas, growing at elevations of up to 1,000 m above sea level on pasturelands, river basins or hillsides.

Moringa oleifera is also known with different names including, horseradish tree, ben oil tree, drumstick tree, miracle tree, and "Mother's Best Friend", Kelor tree (Anwar and Bhanger, 2003, Prabhu et al., 2011). This species was introduced to Africa at the beginning of the twentieth century as a health supplement (Muluvi et al., 1999). The ben oil seems to show promise for the manufacture of soap with high washing efficiency. This makes it suitable for poor areas where people cannot afford buying these products but they have the plant available for use.

This nutritional plant is little known in the western world despite of being considered one of the world's most beneficial trees due to the potential use of each part of plant (Table 1) either as fodder, vegetable or medicine in South Asia (Odebiyi and Sofowora, 1999). The leaves, fruit, flower and immature pods (Figure 1) of this tree are commonly used as a nutritious vegetable in several countries, making it a great potential food source in dry season areas where food could be scarce. Countries such as India, Pakistan and Philippines (Gopalakrishnan et al., 2016; Anwar et al., 2005; Anwar and Bhanger, 2003; D'souza and Kulkarni.1993) use this species widely. Moringa is being used in diverse culinary ways and as a health supplement (McBurney et al., 2004; Fahey, 2005; DanMalam et al., 2001; Iqbal et al., 2006). A leaf powder from the plant can be used for children with malnutrition, pregnant and lactating woman (Price, 1985). For example, In the Philippines, this plant is commonly used to increase the production of milk in lactating women, hence its name of "mother's best friend"; and it has also been prescribed to patients with anemia (Siddhuraju and Becker, 2003; Estrella et al., 2000). 
Interestingly, this species is reported to have natural and organic sunscreens with an SPF value of 2 at low concentrations (2-4\%), giving a 50\% sun protection (Baldisserotto et al., 2018), a potential alternative for use in children in tropical countries.

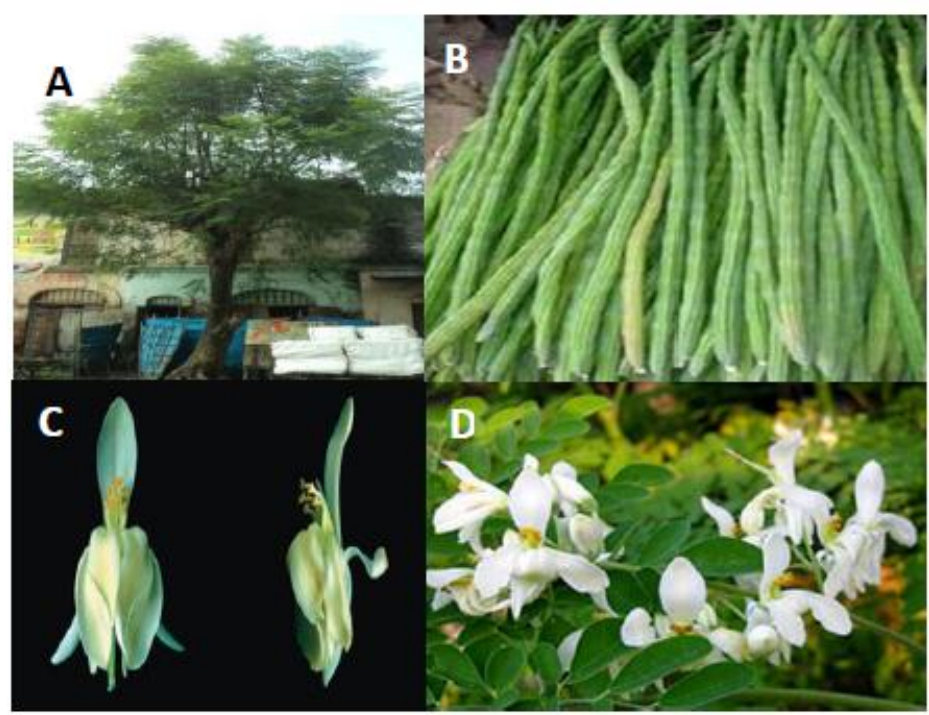

Figure 1. A Moringa oleifera tree planted along a street in Buxipur, Gorakhpur (A), green pods (B); frontal and side view of the flowers (C) and flowering branch (D)

Table 1. Common uses of different parts of Moringa oleifera Lam

\begin{tabular}{|c|c|c|}
\hline \multirow{2}{*}{$\begin{array}{l}\text { plant } \\
\text { parts }\end{array}$} & \multicolumn{2}{|r|}{ Uses / applications } \\
\hline & food & medicine \\
\hline Leaves & Salads, vegetables curries & $\begin{array}{l}\text { Powder for treating tumors; poultice for sores, piles, reduce glandular } \\
\text { swelling, headaches, or body cleanser, to promote digestion; } \\
\text { hypocholesterolemic, juice lowering glucose levels, eye and ear } \\
\text { infection }\end{array}$ \\
\hline Flower & $\begin{array}{l}\text { extracts used for honey } \\
\text { preparations }\end{array}$ & $\begin{array}{l}\text { remedy for tumors, infections, muscle diseases, spleen enlargement } \\
\text { and to lower cholesterol level }\end{array}$ \\
\hline $\begin{array}{l}\text { Pods I } \\
\text { fruits }\end{array}$ & Salad, vegetable & treat malnutrition \\
\hline Seeds & $\begin{array}{l}\text { as a snack, oil for salads, } \\
\text { cooking, cosmetics, } \\
\text { lubricant; water purifying }\end{array}$ & To treat abdominal tumors and to remove harmful bacteria \\
\hline Bark & For tanning & Promote digestion \\
\hline Root & $\begin{array}{l}\text { Used as a substitute for } \\
\text { horseradish }\end{array}$ & $\begin{array}{l}\text { To treat tumors, promote digestion, antilithic, antifertility and } \\
\text { anti-inflammatory. Beneficial against rheumatism, constipation, } \\
\text { kidney pain or back pain. }\end{array}$ \\
\hline
\end{tabular}

\section{Phytochemistry and Chemical Constituents}

The Phytochemicals (chemical compounds) responsible for the properties of this species have not been thoroughly studied (Liu, 2004, Brow and Arthur, 2001). Three structural types of phytochemicals of medicinal interest in this species includes, flavonoids, glucosinolates and phenolic compounds (Saleem, 1995; Manguro and Lemmen, 2007; Kasolo et al., 2010; Amaglo et al., 2010). The phytochemical of leaves of Moringa (Figure 2) can vary depending on the growing climate conditions where the plant grows, the method of collection and processing (Coppin, 2008; Mukunzi et al., 2011). These include tannins, saponins, alkaloids, flavonoids, anthraquinones, glycosides and steroids (Idris and Adamu, 2018). In addition, other compounds have been isolated from leaves, including different types of glycosides (Faizi et al., 1998, 1995, 1994, 1992; Murakami et al., 1998; Miean et al., 2001; Bennett et al., 2003; Wu et al., 2003). Leaves also contain carotenoids, tocopherols and vitamin $\mathrm{C}$ that can prevent free-radical damage linked to many diseases (Smolin 
and Grosvenor, 2007). The root bark is rich in two alkaloids: moringine and moringinine.<smiles>CC(=O)OC1C(C)OC(Oc2ccc(CN=C=S)cc2)C(O)C1O</smiles>

Benzyl isothiocyanate 4-(4'-O-acetyl-Lrhamnopyranosyloxy)

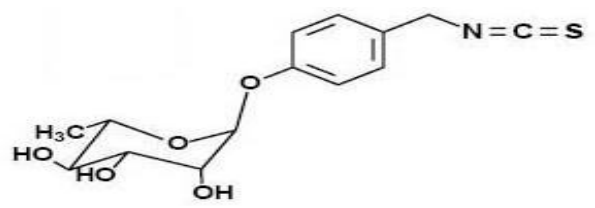

Benzyl isothiocyanate 4-(-L-rhamnopyranosyloxy)

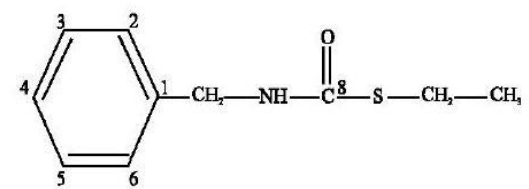

Aglycone of Deoxy- Niaziicine (N-benzyl, S- ethyl thioformate)

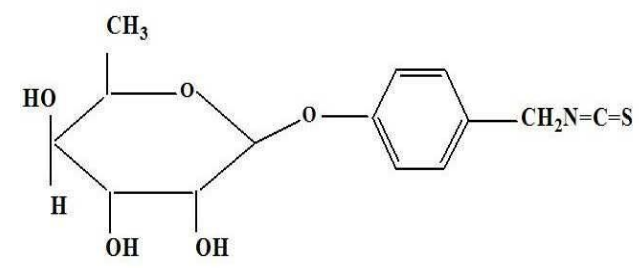

4- ( $\alpha$-L-rhamno Pyroanosyloxy) benzyl isothiacyanate<smiles>C[C@@H]1OC(=O)c2c(O)cccc2C1O</smiles>

4-hydroxy mullein<smiles>CCOC(=S)NNCCc1ccc(OC2OC3C(C)C(O)C(O)C(O)C3O2)cc1</smiles>

Niazimicin<smiles></smiles>

or<smiles>S=C1OC(=S)C2(C=CC3(C=C2)OC(=S)N3Cc2ccccc2)O1</smiles>

Pterygospermin 
<smiles>S=C=NCc1ccccc1</smiles>

Benzyl isothiocyanate<smiles>Cc1cccc(C)c1C(=O)O[Na]</smiles>

Moringyne<smiles></smiles>

Niaziridin<smiles>CC1OC2OC(Oc3ccc(CC#N)cc3)C(O)C(O)C(O)C1O2</smiles>

Niazirin

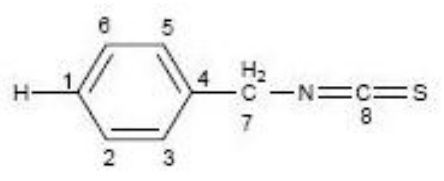

Isothiocyanato methyl benzene

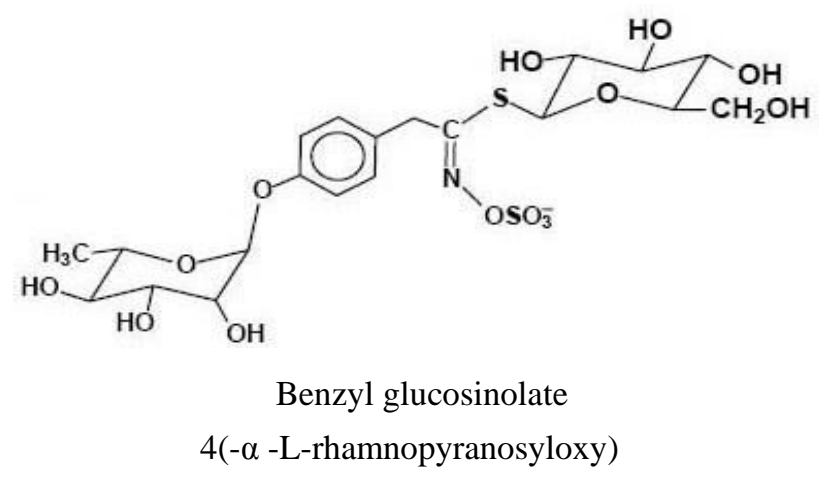

Figure 2. Structures of some phytochemicals from Moringa oleifera

Moringa contains a substantial amount of palmiti, di-oleic, and stearic acids, proteins, saponins, proteins and a variety of vitamins, including Vitamin A, B1, B2, B3, C, nicotinic acid, pyridoxine, ascorbic acid and folic acid (Dahot and Memon 1985). In addition, it is rich in minerals such as iron, calcium, magnesium and phosphorus (Gopalakrishnan et al., 2016). A substantial amount of essential amino acids are found in the pods (Lako et al., 
2007) along with tocopherols (Gomez-Coronado et al., 2004; Sánchez-Machado et al., 2006). All these phytochemicals make Moringa a plant of great value.

\section{Medicinal Value}

Moringa is known in folk medicine in India (Fuglie, 1999.) because of its versatile medicinal properties and it has been used since ancient times by people. It is recognized for its anti-inflammatory, diuretic, abortifacient, antispasmodic, emmenagogue and ecbolic properties and it has been reported to be useful in the treatment of tumors, leukoderma and biliousness etc. (Das et al., 1957, Shaw and Jana, 1982). Interestingly, ethanolic extracts of Moringa leaves seem to have a radioprotection effect against damaged induced by high doses of ionizing radiation (Elwan et al., 2018) showing the versatility and potential uses of this plant.

\subsection{Antimicrobial Properties}

Virtually all parts of this species have shown antimicrobial properties (Caceres et al., 1991; Ali et al., 1999; Senthil Kumar and Reetha 2009); this includes leaves, bark, fruit, root and flowers (Khalil 1996; Tsaknis et al., 1999). This is important because there is a great need for antimicrobial compound in the medical community due to the development of antibiotic resistance. More studies need to be done to evaluate the use of this species and to isolate the proper compounds that can be use in allopathic medicine.

\subsection{Antioxidant Properties}

The antioxidant properties of this species is important to prevent of damage to important macromolecules such as DNA, proteins and lipids so cells can function properly (Ryter et al., 2007; Limon-Pacheco and Gonsebatt, 2009). The seeds and leaves of Moringa are a good source of antioxidants (Chumark et al., 2008) with $65.1 \%$ in methanolic extracts and 66.8\% in ethanolic extracts (Lalas and Tsaknis, 2002; Siddhuraju and Becker, 2003). Some studies have shown that quercetin and kaempferol seem to be responsible for this antioxidant activity (Bajpai et al., 2005; Siddhuraju and Becker, 2003). The qualitative properties of antioxidant in Moringa have been highlighted. Sreelatha and Padma (2009) indicated that the antioxidants in both mature and young leaves have a great potential to scavenge free radicals, along with nutritional antioxidants such as Vitamins A, C, and E (Limon-Pacheco and Gonsebatt, 2009). The highest therapeutic value of M. oleifera is further substantiated in terms of its high antioxidant level present in leaves, seeds, flowers and pods (Chumark et al., 2008; Verma et al., 2009; Atawodi et al., 2010). Kumar et al. (2007) demonstrated these antioxidant properties could be responsible for reduction of the chance of cancer development and other damage to the cell.

\subsection{Anti-inflammatory Properties}

The pathophysiology of many diseases, such as diabetes, obesity, hypertension and others can involve immunological responses (Rana et al., 2007). Leaf extracts from Moringa leaf extracts seem to modulate cellular immunity in rats and mice (Sudha et al., 2010; Gupta et al., 2010). Leaf preparations have shown anti-inflammatory properties in rodent models (Sulaiman et al., 2008; Mahajan and Mehta, 2009). Studies suggest that the anti- inflammatory properties are stronger in fruit and seed extracts (Mahajan and Mehta, 2010; Cheenpracha et al., 2010; Muangnoi et al., 2011).

\subsection{Hypocholesterolemic Activity}

Moringa leaves contain phytosterols (Jain et al., 2010); that seem to be implicated in the reduction of cholesterol uptake by the intestines (Lin et al., 2010). It is possible that this could result in a decrease in cholesterol levels and an increase in excreted cholesterol seen in experimental rodents (Mehta et al., 2003; Jain et al., 2010). The high-fiber content $(12 \% \mathrm{w} / \mathrm{w})$ may also play a role in the hypocholesterolemic effect due to enhanced excretion/gastric emptying (Bortolotti et al., 2008; Joshi and Mehta, 2010).

\subsection{Anti-asthmatic Activity}

The Moringa alkaloid moringine closely resembles ephedrine, inducing relaxation of the bronchioles (Kirtikar and Basu, 1975). The seeds and kernels of Moringa have been used successfully for the treatment of bronchial asthma, by decreasing the severity of the symptoms, resulting in the improvement of respiratory problems in patients (Agrawal and Mehta, 2008).

\subsection{Analgesic Activity}

Ethanolic extracts of Moringa fruits have shown good analgesic properties when tested in Male Sprague-Dawley rats (Rao et al., 2008). The authors used the Ugo Basile 37215 analgesia-meter to evaluate pain and adjuvant-induced arthritis to evaluate anti-inflammatory properties. They found strong analgesic activity and anti-inflammatory properties in this plant. Sutar et al. (2008) used Wister male albino rats and tested pain threshold using the licking or paw/jumping response of the animal and the tail immersion method. The authors 
found that Moringa seems to have a strong analgesic activity. There is a great potential for this plant to be used by people that may not have access to more expensive analgesics but have the plant available for their use. In addition, extracts of this plant could eventually be commercialized for medicinal uses.

\subsection{Antidiabetic Activity}

Experiments in Wistar and Goto-Kakizaki (GK) rats with type 2 diabetes show a positive effect of Moringa leaves, with a significant decrease in blood glucose levels (Ndong et al., 2007). In addition, in high-fat-diet mouse models, the extracts of this plant have shown improved glucose tolerance (Jaja-Chimedza et al., 2018). The lowering blood sugar levels within $3 \mathrm{~h}$ after ingestion has been observed (Mittal et al., 2007) and is likely to be due to extracts' inhibitory activity against $\alpha$-Glucosidase enzyme (Natsir et al., 2018). It is possible that polyphenols such as 3-glycoside, kaempferol glycosides and others (Ndong et al., 2007) could have an effect in this antidiabetic activity. Studies have shown the antioxidant activity of Moringa can rescue apoptosis of beta cells, therefore preventing damage to these cells, leading to the beneficial properties against diabetes (Al-Malki et al., 2015; Mbikay, 2012; Kaneto et al., 1999). Additional studies may lead to the commercialization of Moringa extracts for conventional treatment of diabetes.

\section{Conclusion}

This review shows that different parts of Moringa (leaves, flowers, fruits and seeds) possess a great variety of compounds with high nutritional and medicinal content that could make it an ideal complementary and alternative medicine and/or nutritional supplement. The presence of antimicrobial compounds could lead to the development of alternative treatments against infectious diseases. Research has shown that every part of the plant has some medicinal application that could be further develop to produce more affordable medicines. $M$. oleifera is nutritional and medicinally very active against free radicals formed during oxidative stress due to the strong phytochemical constituents present in virtually all parts of the plant. There is a great potential for the widespread use of this plant.

\section{Acknowledgements}

The authors are thankful to the Head, Department of Botany, DDU Gorakhpur University, Gorakhpur and to SCST, U.P. for financial assistance. O.R.K. would like to acknowledge Utah Valley University for the funding provided.

\section{References}

Al-Malki, A. L., \& El Rabey, H. A. (2015). The antidiabetic effect of low doses of Moringa oleifera Lam. Seeds on Streptozotocin induced diabetes and diabetic nephropathy in male rats. Biomed. Res. Int., 2015, 1-13. https://doi.org/10.1155/2015/381040

Anwar, F., Ashraf, M., \& Bhanger MI. (2005). Interprovenance Variation in the composition of Moringa oleifera oilseeds from Pakistan. J Am oil chem. Soc., 82, 45-51. https://doi.org/10.1007/s11746-005-1041-1

Anwar, F., \& Bhanger, M. I. (2003). Analytical characterization of Moringa oleifera seed oil grown in temperate regions of Pakistan. J Agric food chem., 51, 6558-6563. https://doi.org/10.1021/jf0209894

Ali, M. S., Azhar, I., Amtul, Z., Ahmad, V. U., \& Usmanghni, K. (1999). Antimicrobial screening of some Caesalpiniaceae. Fitoterapia, 70, 299-304. https://doi.org/10.1016/S0367-326X(99)00015-5

Amaglo, N. K., Bennett, R. N., Lo Curto, R. B., Rosa, E. A. S., Lo Turco, V., Giuffrid, A., ... Timpo, G. M. (2010). Profiling selected phytochemicals and nutrients in different tissues of the multipurpose tree Moringa oleifera L., grown in Ghana. Food Chem., 122, 1047-1054. https://doi.org/10.1016/j.foodchem.2010.03.073

Atawodi, S. E., Atawodi, J. C., Idakwo, G. A., Pfundstein, B., Haubner, R., Wurtele, G., Bartsch, H., \& Owen, R. W. (2010). Evaluation of the polyphenol content and antioxidant properties of methanol extracts of the leaves, stem, and root barks of Moringa oleifera Lam. J. Med. Food, 13, 710-716. https://doi.org/10.1089/jmf.2009.0057

Agrawal, B., \& Mehta, A. (2008). Antiasthmatic activity of Moringa oleifera Lam: A clinical study. Indian J. Pharmacol., 40, 28-31. https://doi.org/10.4103/0253-7613.40486

Baldisserotto, A., Buso, P., Radice, M., \& Vertuani, S. (2018). Moringa oleifera leaf extracts as multifunctional ingredients for "Natural and Organic" sunscreens and photoprotective preparations. Molecules, 23(3), 664. https://doi.org/10.3390/molecules23030664

Bortolotti, M., Levorato, M., Lugli, A., \& Mazzero, G. (2008). Effect of a balanced mixture of dietary fibers on 
gastric emptying, intestinal transit and body weight. Ann. Nutr. Metab., 52, 221-226. https://doi.org/10.1159/000138127

Bennett, R. N., Mellon, F. A., Foidl, N., Pratt, J. H., Dupoint, S. M., Perkins, L., \& Kroon, P. A. (2003). Profiling Glucosinolates and phenolics in vegetative and reproductive tissues of the multi-purpose trees M. oleifera $\mathrm{L}$. (Horseradish Tree) and Moringa stenopetala L. J. Agri. Food Chem., 51, 3546-3553. https://doi.org/10.1021/jf0211480

Caceres, A., Cabrera, O., Morales, O., Mollinedo, P., \& Mendia P. (1991). Pharmacological properties of Moringa oleifera. Preliminary screening for antimicrobial activity, Journal of Ethnopharmacology, 33, 213-216. https://doi.org/10.1016/0378-8741(91)90078-R

Chumark, P., Khunawat, P., Sanvarinda, Y., Phornchirasilp, S., Morales, P. N., Phivthong-ngam, L., ... Pongrapeeporn, K. S. (2008). The in vitro and ex vivo antioxidant properties, hypolipidaemic and antiatherosclerotic activities of the water extract of Moringa oleifera Lam. leaves. J. of Ethnopharmacology, 116, 439-446. https://doi.org/10.1016/j.jep.2007.12.010

Cheenpracha, S., Park, E. J., Yoshida, W. Y., Barit, C., Wall, M., Pezzuto, J. M., \& Chang, L. C. (2010). Potential anti-inflammatory phenolic glycosides from the medicinal plant Moringa oleifera fruits. Bioorg. Med. Chem., 18, 6598-6602. https://doi.org/10.1016/j.bmc.2010.03.057

Coppin, J. (2008). A Study of the Nutritional and Medicinal Values of Moringa oleifera Leaves from sub-Saharan Africa: Ghana, Rwanda, Senegal and Zambia. M.Sc. thesis, Rutgers University-Graduate School-New Brunswick, New Brunswick.

D’Souza, J., \& Kulkarni, A. R. (1993). Comparative Studies on nutritive values of tender foliage of seedlings and mature plants of Moringa oleifera Lam. J Econ Taxon Bot., 17, 479-485.

DanMalam, H. U., Abubakar, Z., \& Katsayal, U. A. (2001). Pharmacognostic studies on the leaves of Moringa oleifera. Nigerian Journal of Natural Product and Medicine, 5, 45-49.

Dahot, M. U., \& Memon, A. R. (1985). Nutritive significance of oil extracted from Moringa oleifera seeds, $J$ Pharm Univ Karachi, 3(2), 75-80.

Das, B. R., Kurup, P. A., \& Narasimha, R. P. L. (1957). Antibiotic principle from Moringa pterygosperma. Part VII. Antibacterial activity and chemical structure of 6 compounds related to pterygospermin, Indian Journal of Medical Research, 45, 191-196.

Elway, A. M., Salama, A. A., Sayed, A. M., Ghoneim, A. M., Elsaied, A. A., Ibrahim, F. A., \& Elnasharty, M. M. M. (2018). Biophysical and biochemical roles of Moringa oleifera leaves as radioprotector. Progress in Biophysics and Molecular Biology, 140, 142-149. https://doi.org/10.1016/j.pbiomolbio.2018.06.003

Estrella, M. C. P., Mantaring, J. B. V., \& David, G. Z. (2000). A double blind randomized controlled trial on the use of malunggay (Moringa oleifera) for augmentation of the volume of breast milk among non-nursing mothers of preterm infants. Philipp J Pediatr., 49, 3-6.

Fahey, J. W. (2005). M. oleifera: A Review of the Medical Evidence for Its nutritional, therapeutic, and prophylactic property. Part 1. Trees for Life Journal, 1, 5.

Faizi, S., Siddiqui, B. S., Saleem, R., Siddiqui, S., Aftab, K., \& Giliani, A. H. (1994) Isolation and structure elucidation of new nitrile and mustard oil glycosides from M. oleifera. J. Nat. Prod., 57, 1256-1261. https://doi.org/10.1021/np50111a011

Faizi, S., Siddiqui, B. S., Saleem, R., Siddiqui, S., Aftab, K., \& Giliani, A. H. (1995). Fully acetylated carbamate and hypotensive thiocarbamate glycosides from M. oleifera. J. Phytochemistry, 38, 957-963. https://doi.org/10.1016/0031-9422(94)00729-D

Fuglie, L. J. (1999). The Miracle Tree: Moringa oleifera: Natural Nutrition for the Tropics. Church World Service, Dakar, 1, 68.

Gomez-Coronado, D. J. M., Ibanez, E., Ruperez, F. J., \& Barbas, C. (2004). Tocopherol measurement in edible products of vegetable origin. J. Chromatography A., 1054, 227-233.

https://doi.org/10.1016/j.chroma.2004.08.072

Gopalakrishnan, L., Doriya, K., \& Kumar, D. V. (2016). Moringa oleifera: A review on nutritive importance and its medicinal application. Food Science and Human Wellness, 5, 49-56.

https://doi.org/10.1016/j.fshw.2016.04.001 
Gupta, A., Gautam, M. K., Singh, R. K., Kumar, M. V., Rao, C. V., Goel, R. K., \& Anupurba, S. (2010). Immunomodulatory effect of Moringa oleifera Lam. extract on cyclophosphamide induced toxicity in mice. Indian J. Exp. Biol., 48, 1157-1160.

Idris, S. B. \& Adamu, U. R. (2018). Phytochemicals and uses of Moringa oleifera leaves in humans and animals in Sokoto. Journal of Animal Science and Veterinary Medicine, 3, 30-34.

Iqbal, S., \& Bhanger, M. I. (2006) Effect of season and production location on antioxidant activity of Moringa oleifera leaves grown in Pakistan. J. of Food Comp. and Anal., 19, 544-551. https://doi.org/10.1016/j.jfca.2005.05.001

Jaja-Chimedza, A., Zhang, L., Wolff, K., Graf, B. L., Kuhn, P., Moskal, K., ... Raskin, I. (2018). A dietary isothiocynate-enriched moringa (Moringa oleifera) seed extract improves glucose tolerance in a high-fat-diet mouse model and modulates the gut microbiome. Journal of functional Foods, 47, 376-385. https://doi.org/10.1016/j.jff.2018.05.056

Jahn, S. A. A. (1988). Using Moringa Seeds as Coagulants in Developing Countries. Journal Awwa Management Operations, 80(6), 43-50. https://doi.org/10.1002/j.1551-8833.1988.tb03052.x

Jain, P. J., Patil, S. D., Haswani, N. G., Girase, M. V., \& Surana, S. J. (2010). Hypolipidemic activity of Moringa oleifera Lam., Moringaceae, on high fat died-induced hyperlipidemia in albino rats. Braz. J. Pharmacogn, 20, 969-973. https://doi.org/10.1590/S0102-695X2010005000038

Kaneto, H., Kajimoto, Y., Miyagawa, J., Matsuoka, T., Fujitani, Y., Umayahara, Y., ... Hori, M. (1999). Beneficial effects of antioxidants in diabetes: possible protection of pancreatic $\beta$-cells against glucose toxicity. Diabetes, 48, 2398-2406. https://doi.org/10.2337/diabetes.48.12.2398

Kirtikar, K. R., \& Basu, B. D. (1975). Indian Medicinal Plants. In: Singh B. And M. P. Singh (eds) Dehradun, 676-683.

Kasolo, J. N., Bimenya, G. S., Ojok, L., Ochleng, J., \& Ogwal-Okeng, J. W. (2010). Phyochemicals and uses of Moringa oleifera leaves in Ugandan rural communities. J. Med. Plant Res., 4, 753-757.

Lako, J., Trenerry, V. C., Wahlqvist, M., Wattanapenpaiboon, N., Southeeswaran, S., \& Premier, R. (2007). Phytochemical flavonols, carotenoids and the antioxidant properties of a wide selection of Fijian fruit, vegetables and other readily available foods. Food Chemistry, 101(4), 1727-1741. https://doi.org/10.1016/j.foodchem.2006.01.031

Limon-Pacheco, J., \& Gonsebatt, M. E. (2009). The role of antioxidants and antioxidant-related enzymes in protective responses to environmentally induced oxidative stress. Mutat. Res., 674, 137-147. https://doi.org/10.1016/j.mrgentox.2008.09.015

Lin, X., Racette, S. B., Lefevre, M., Spearie, C. A., Most, M., Ma, L., \& Ostlund, R. E. Jr. (2010). The effects of phytosterols present in natural food matrices on cholesterol metabolism and LDL-cholesterol: a controlled feeding trial. Eur. J. Clin. Nutr., 64, 1481-1487. https://doi.org/10.1038/ejen.2010.180

Mabberley, D. J. (2017). Mabberley's Plant-book - a portable dictionary of plants, their classification and uses. 4th edition. Cambridge University Press. https://doi.org/10.1017/9781316335581

Mahajan, S., \& Mehta, A. (2009). Curative effect of hydroalcoholic extract of leaves of Moringa oleifera Lam. against adjuvant induced established arthritis in rats. Niger. J. Nat. Prod. Med., 13, 13-22.

Mahajan, S. G., \& Mehta, A. A. (2010). Immunosuppressive activity of ethanolic extract of seeds of Moringa oleifera Lam. in experimental immune inflammation. J. Ethnopharmacol., 130, 183-186. https://doi.org/10.1016/j.jep.2010.04.024

Manguro, L. O., \& Lemmen, P. (2007). Phenolics of Moringa oleifera leaves. Nat. Prod. Res., 21, 56-68. https://doi.org/10.1080/14786410601035811

Mbikay, M. (2012). Therapeutic potential of Moringa oleifera leaves in chronic hyperglycemia and dyslipidemia: a review. Front. Pharmacol., 3, 1-12. https://doi.org/10.3389/fphar.2012.00024

Mehta, K., Balaraman, R., Amin, A. H., Bafna, P. A., \& Gulati, O. D. (2003). Effect of fruits of Moringa oleifera on the lipid profile of normal and hypercholesterolaemic rabbits. J. Ethnopharmacol., 86, 191-195. https://doi.org/10.1016/S0378-8741(03)00075-8

Morton, J. F. (1991). The horseradish tree, Moringa pterigosperma (Moringaceae). A boon to arid land E con Bot., 45, 318-333. https://doi.org/10.1007/BF02887070 
McBurney, R. P., Griffin, C., Paul, A. A., \& Greenberg, D. C. (2004). The nutritional composition of African wild food plants: from compilation to utilization. Journal of Food Composition and Analysis, 17, 277-289. https://doi.org/10.1016/j.jfca.2004.03.008

Miean, H. K., \& Mohamed, S. (2001). Flavonoid (Myricetin, Quercetin, Kaempferol, Luteolin, and Apigenin) Content of Edible Topical Plants. J. Agri. Food Chem., 49, 3106-3112. https://doi.org/10.1021/jf000892m

Murakami, A., Kitazono, Y., Jiwajinda, S., Koshimizu, K., \& Ohigashi, H. (1998). Naizimin, A thiocarbamate from the leaves of $M$. oleifera, holds a strict structural requirement for inhibition of tumour-promoter-induced Epstein-Barr virus activation. Planta Med., 64, 319-323. https://doi.org/10.1055/s-2006-957442

Muluvi, G. M., Sprent, J. I., Soranzo, N., Provan, J., Odee, D., Folklard, G., McNicol, J. W., \& Powell, W. (1999). Amplified fragment length polymorphism (AFLP) analysis of genetic variation in M. oleifera Lam. J. of Mol. Ecol., 8, 463-470. https://doi.org/10.1046/j.1365-294X.1999.00589.x

Mughal, M. H., Ali, G., Srivastava, P. S., \& Iqbal, M. (1999). Improvement of drumstick (Moringa pterygosperma Gaertn.) - a unique source of food and medicine through tissue culture, Hamdard Med., 42, $37-42$.

Muangnoi, C., Chingsuwanrote, P., Praengamthanachoti, P., Svasti, S., \& Tuntipopipat, S. (2011). Moringa oleifera pod inhibits inflammatory mediator production by lipopolysaccharide-stimulated RAW 264.7 murine macrophage cell lines. Inflammation, 35(2), 445-455. https://doi.org/10.1007/s10753-011-9334-4

Mukunzi, D., Nsor-Atindana, J., Xiaoming, Z., Gahungu, A., Karangwa, E., Mukamurezi, G., ... Arief, N. J. (2011). Comparison of volatile profile of Moringa oleifera leaves from Rwanda and China using HS-SPME. Pakistan J. Nutr., 10, 602-608. https://doi.org/10.3923/pjn.2011.602.608

Mittal, M., Mittal, P., \& Agarwal, A.C. (2007). Pharmacognostic and phytochemical investigation of antidiabetic activity of Moringa oleifera lam leaf. Ind. Pharm., 6, 70-72.

Ndong, M., Uehara, M., Katsumata, S., \& Suzuki, K. (2007). Effects of oral administration of Moringa oleifera Lam on glucose tolerance in gotokakizaki and wistar rats. J. Clin. Biochem. Nutr., 40, 229-233. https://doi.org/10.3164/jcbn.40.229

Nadkarni, A. K. (1976). Indian Materia Medica. Popular Prakashan: Bombay, 810-816.

Natsir, H., Wahab, A. W., Laga, A., \& Arif, A. R. (2018). Inhibitory activities of Moringa oleifera leaf extract against $\alpha$-glucosidase enzyme in vitro. Journal of Physics: Conf. Series, 979, 012-019. https://doi.org/10.1088/1742-6596/979/1/012019

Odebiyi, A., \& Sofowora, E. A. (1999). Phytochemical screenings of Nigerian medicinal plants part 11. Lyodia, 44, 234-246.

Odee, D. (1998). Forest biotechnology research in drylands of Kenya: the development of Moringa species. Dryland Biodiversity, 2, 7-8.

Pandey, V. N., Gupta, N., Dwiwedi, A. K., Srivastav, A. K. \& Pandey, R. K. (2006). Nutraceutical plants, public health and Environment in North Eastern Terai Region of Uttar Pradesh. SCITECH.OPI, I. 1-24

Price, M. L. (1985). The Moringa Tree, ECHO Technical Note (revised 2000 by Kristin Davis).

Prabhu, K., Murugan, K., Nareshkumar, A., Ramasubramanian, N., \& Bragadeeswaran, S. (2011). Larvicidal and repellent potential of Moringa oleifera against malarial vector, Anopheles stephensi Liston (Insecta: Diptera: Culicidae). Asian Pacif. J. Trop. Biomed., 1(2), 124-129. https://doi.org/10.1016/S2221-1691(11)60009-9

Ramachandran, C., Peter, K. V., \& Gopalakrishnan, P. K. (1980). Drumstick (Moringa oleifera): a multipurpose Indian vegetable. Economic Botany, 34, 276-283. https://doi.org/10.1007/BF02858648

Rana, J. S., Nieuwdorp, M., Jukema, J. W., \& Kastelein, J. J. (2007). Cardiovascular metabolic syndrome - an interplay of obesity, inflammation, diabetes and coronary heart disease. Diabetes Obes. Metab., 9, 218-232. https://doi.org/10.1111/j.1463-1326.2006.00594.x

Ryter, S. W., Kim, H. P., Hoetzel, A., Park, J. W., Nakahira, K., Wang, X., \& Choi, A. M. (2007). Mechanisms of cell death in oxidative stress. Antioxid. Redox Signal, 9, 49-89. https://doi.org/10.1089/ars.2007.9.49

Rao, C. H., Hussain, M. T., Verma, A. R., Kumar, N., Vijayakumar, M., \& Reddy, G. D. (2008). Evaluation of the analgesic and anti-inflammatory activity of Moringa concanensis tender fruits. Tradit. Med., 3, 95-103.

Sutar, N. G., Bonde, C. G., Patil, V. V., Narkhede, S. B., Patil, A. P., \& Kakade, R. T. (2008). Analgesic activity 
of seeds of Moringa oleifera Lam. Int. J. Green Pharm., Apr-June, 108-110.

https://doi.org/10.4103/0973-8258.41182

Saleem, R. (1995). Study of Chemical Constituents of Moringa Oleifera Lam. Ph.D. thesis, University of Karachi, Karachi.

Siddhuraju, P., \& Becker, K. (2003). Antioxidant properties of various solvent extracts of total phenolic constituents from three different agro-climatic origins of drumstick tree (Moringa oleifera Lam). J Agric Food chem., 15, 2144-2155. https://doi.org/10.1021/jf020444+

Somali, M. A., Bajnedi, M. A., \& Faimani, S. S. (1984). Chemical composition and characteristics of Moringa peregrine seeds and seed oil. J Am oil chem. Soc., 61, 85-86. https://doi.org/10.1007/BF02672051

Sánchez-Machado, D. I., Lopez-Cervantes, J., \& Rios Vasquez, N. J. (2006). High performance liquid chromatography method to measure a- and g-tocopherol in leaves, flowers and fresh beans from M. oleifera. J. Chromatogr. A., 1105(1-2), 111-114. https://doi.org/10.1016/j.chroma.2005.07.048

Smolin, L. A., \& Grosvenor, M. B. (2007). Nutrition: Science \& Application. John Wiley \& Sons.

Senthil, K. P. K., \& Reetha, D. (2009). Screening of Antimicrobial Properties of Certain Indian Medicinal Plants. J. Phytol., 1, 193-198.

Shaw, B. P., \& Jana, P. (1982). Clinical assessment of Sigru (Moringa oleifera Lam) on Mutrakrichra (lower urinary tract infection). Nagarjun, 231-235.

Sreelatha, S., \& Padma, P. R. (2009). Antioxidant activity and total phenolic content of Moringa oleifera leaves in two stages of maturity. Plant Foods Hum. Nutr., 64, 303-311. https://doi.org/10.1007/s11130-009-0141-0

Sudha, P., Asdaq, S. M., Dhamingi, S. S., \& Chandrakala, G. K. (2010). Immunomodulatory activity of methanolic leaf extract of Moringa oleifera in animals. Indian J. Physiol. Pharmacol., 54, 133.

Sulaiman, M. R., Zakaria, Z. A., Bujarimin, A. S., Somchit, M. N., Israf, D. A., \& Moin, S. (2008). Evaluation of Moringa oleifera aqueous extract for antinociceptive and anti-inflammatory activities in animal models. Pharmacol. Biol., 46, 838-845. https://doi.org/10.1080/13880200802366710

Tsaknis, J., Lalas, S., Gergis, V., Douroglou, V., \& Spiliotis, V. (1999). Characterization of Moringa oleifera variety Mbololo seed oil of Kenya, Journal of Agricultural and Food Chemistry, 47, 4495-4499. https://doi.org/10.1021/jf9904214

The Wealth of India - (A dictionary of Indian raw materials and industrial products). (1962). Raw Materials. VolVI: EM, Council of Scientific and Industrial Research, New Delhi, 425-429.

UICC/ WHO (2005). Global Action Against Cancer NOW. Geneva: UICC and WHO Publications Department.

Verma, A. R., Vijayakumar, M., Mathela, C. S., \& Rao, C. V. (2009). In vitro and in vivo antioxidant properties of different fractions of Moringa oleifera leaves. Food Chem. Toxicol., 47, 2196-2201. https://doi.org/10.1016/j.fct.2009.06.005

Wu, Q., Wang, M., \& Simon, J. E. (2003). Determination of isoflavones in red clover and related species by high-performance liquid chromatography combined with ultraviolet and mass spectrometric detection. $J$. Chromatography A, 1016, 195-209. https://doi.org/10.1016/j.chroma.2003.08.001

\section{Copyrights}

Copyright for this article is retained by the author(s), with first publication rights granted to the journal.

This is an open-access article distributed under the terms and conditions of the Creative Commons Attribution license (http://creativecommons.org/licenses/by/4.0/). 